\title{
Assessing Students' Speaking Skill through Peer Assessment
}

\section{Abstract}

This paper depicts peer assessment implementation in showing talking expertise in Senior High School understudies. The examination was sorted as enlightening investigation in which the analyst filled in as a functioning spectator. The exploration members in this examination were the primary year understudies and an instructor who applied companion appraisal procedure in the senior secondary school in Sukabumi. The analyst applied a resulting interaction strategy by noticing the homeroom utilizing perception sheet, and taking field notes to see the cycle of execution of friend evaluation. In examining the information, the specialist utilized information decrease, information show, and confirmation. The execution interaction of companion appraisal was appeared by the study hall perception in three stages; pre-execution of friend evaluation, during peer appraisal, and post friend evaluation. The specialist likewise tracked down that the fruitful execution of companion evaluation was a result of the educator's accentuation on offering score to the friends and raising the understudies' inspiration to direct companion appraisal, making them certain to play out the peer assessment measure.

Keywords: peer assessment, speaking skill

Speaking becomes one of the primary aspects for the EFL students in learning English as a foreign language. Through speaking, the students can do face to face communication and comprehend about the conversation. What's more, it enables them to convey their thoughts, knowledge, experiences, and ideas in the spoken form. For instance, the students carry out a small discussion during the teaching and learning process, tell their activities to their friends and others. In addition, Sharma (2018) stated that speaking is also used to express feeling, facts, as well as opinions spontaneously when the student communicates to others. Therefore, speaking is needed to be developed especially by the students in senior high school level.

In order to find out the students' progress about their speaking skill, it needs an appropriate technique to assess their speaking activities. This present research promotes peer assessment to be applied to the senior high students in learning English-speaking skill. Peer assessment is aimed to observe the students' ability of speaking skill through providing constructive 
comments, recoding their feedbacks, and developing students' awareness about their speaking ability. The implementation of a peer assessment can be an opportunity for the students to become an active learner in the classroom. Through the peer feedback, they will offer a correction and input to their friends and also share their ideas as the improvement of the learning process. Furthermore, it may be utilized as the learning tool for the students and achieve the social practice including community, participation, repertoires, and reification. In accordance to the importance of peer assessment, the writer seems to suggest that the students' perspective related to its implementation is still needed to be explored. In addition, most of the previous researches emphasize on the writing skill, whereas this study is focusing on the speaking skill. Therefore, it is still interesting through the indepth investigation.

Based on the focus of the research, researches about peer assessment have been conducted by several scholars with different perspectives. For instance, Wang (2016) seems to indicate that peer assessment promotes the students' competence in English writing skill. Based on his research, the writer provides some criteria during the implementation of peer assessment, such as content, grammar, vocabularies, emotion, expression, idioms and others. Then, the teachers can monitor the students' progress from peer assessment that has been assessed by the other students. Another previous research is carried out by Astuti (2013) which examined the effect of peer assessment in improving academic students. It seems to suggest that it has improved the quality of students writing significantly. Another related study is a research entitled The Effect of Peer Assessment on Writing Anxiety in Turkish EFL Learners which conducted by Yastibas and Yastibas (2015), it indicated that peer assessment could decrease the students' anxiety, increase their confident, and improve their writing ability through collaboration to each other.

In accordance to the previous studies, it seems to indicate that the peer assessment can be utilized to assess the speaking skill on various levels and most of the researches are succeed to give the positive impact to the students after obtaining the assessment. Therefore, to specify this research, 
the writers focus on investigating the students' perception on peer assessment particularly on the senior high school students. Moreover, the aim of this research is exploring the students' perception of peer assessment towards speaking skill. The data will be administrated through descriptive qualitative research.

This study was conducted descriptively in which the researcher served as an active observer in collecting the data. It means that the researcher came into one of the classes in senior high school of Methodist Banda Aceh to observe the implementation of peer assessment in speaking skill. Qualitative method is followed by a description of classroom behaviors, classification of processes, and more subjective inferences toward generalization. The general goal of qualitative approach is to provide rich, descriptive data about what happens in the second language classroom.

To get data collection on the field, the researcher used two instruments. They were observation sheet and field note. Observation was very important to obtain main data for this study where the researcher observed the implementation of peer assessment in speaking skill in the class. The researcher used observation sheet to help the researcher following the activity in the classroom. The researcher as a non-participant observer came to the class observing the implementation of peer assessment in the class by recording and taking notes. The researcher noted every single things in three steps of observation; pre implementation of peer assessment, during peer assessment, and post implementation of peer assessment. The researcher did not involve in any activities in the classroom because it was believed to deviate the objectivity of peer assessment.

The researcher also took notes about the interesting activities, place, date, time, and unusual movements in the class. The field note was also used to note about students' seat arrangement, questions, absenteeism, and all of the unexpected things that happened in the classroom. This data collection helped the researcher to figure out the implementation of peer assessment.

Data analysis was conducted during the study for solving research 
problem. In this chapter the writer adopted the framework developed by Miles and Huberman $(1994$, p. 36) to describe the major phases of data analysis; data reduction, data display, and verification.

Data reduction refers to the process of collecting the mass of information that the researcher may obtain during the study which can be reduced and organized. The raw data was reduced for choosing the main data, focusing on important ones, and searching for the concepts and model by reviewing the result of observation and reading the questionnaire findings.

Data display is organized and compressed information that has been reduced and can be displayed as a text, diagram, chart, or table that provides a new way of the data (Miles \&Huberman, 1994, p. 38). In this stage, the data of this study that had been reduced was displayed by the researcher. This process allowed the writer to conclude the research and got answers for the research problems.

Verification is the in-depth assessment stage for getting conclusions. After all the questionnaire results were tabulated, it made researcher easier to draw conclusions to answer the research questions. The researcher drew conclusions on the perception of students toward peer assessment through questionnaire analyzed.

Peer assessment was effectively carried out in senior secondary school in Sukabumi due to the educator gave an unmistakable clarification about the meaning of companion evaluation, its methods and its advantages to the understudies. The educator likewise settled trust among understudies to fabricate trust while doing the appraisal. A reasonable reason about doing this appraisal made the companion evaluation effective.

Peer assessment can be carried out in the homeroom effectively with a reasonable clarification from the instructor. The educator additionally didn't need to stress over the consequence of peer assessment peer evaluation execution was centered more around the cycle than on the eventual outcome. The manner in which the educator did the pre-carried out peer evaluation, during peer appraisal, and post-executed of companion 
evaluation was a pivotal factor in peer evaluation execution. The educator could set up trust among understudies. An uncommon execution of companion evaluation in first year of Methodist class was because of the less association of the understudies in deciding the rubric score. On the off chance that there are instructors who need to execute peer evaluation in their homeroom, they can include understudies in deciding score of the rubric by talking about what focuses need and need not be surveyed in the talking execution. 


\section{REFERENCES}

Albana, H. H., Marzuki, A. G., Alek, A., \& Hidayat, D. N. (2020). Cohesive Devices in Student's Writing (A Discourse Analysis on Argumentative Text). Jurnal Pendidikan Humaniora, 8(1), 6-11.

Alek, A., Marzuki, A. G., Farkhan, M., \& Deni, R. (2020). Self-Assessment in Exploring EFL Young learners' Speaking Skill. Al-Ta lim Journal, 27(2), 208-214.

Alek, A., Marzuki, A. G., Farkhan, M., Surahman, D., Daryanto, D., \& Febrianto, S. (2020). Computer Based Testing in Senior High School on National Examination. Indonesian Journal of Learning Education and Counseling, 2(2), 204-210.

Angeles: University of California.

Brown, D. H. (2004). Language Assessment: Principles and Classroom Chan, C. (2010). Assessment: Self and Peer Assessment, Assessment Fajar, R. (2019). THE EFFECT OF PEER ASSESSMENT TOWARDS STUDENTS'SPEAKING SKILL AT SEMESTER II OF STIE MUHAMMADIYAH JAMBI 2018-2019. Celtic: A Journal of Culture, English Language Teaching, Literature and Linguistics, 6(2), 26-32.

Falchikov, N. (1995). Peer feedback marking: Developing peer assessment. Innovations in Education and training International, 32(2), 175-187.

Fatimah, A. S., Santiana, S., \& Saputra, Y. (2019). Digital Comic: An Innovation of Using Toondoo As Media Technology for Teaching English Short Story. English Review: Journal of English Education, 7(2), 101-108.

Hansen, J.A., Andree. M. 2019. Using and Rejecting Peer Feedback in the Science Classroom: A Study of Students' Negotiation on How to Use Peer Feedback when Designing Experiments. Research in Science \&Technological Education. 1-20.

Herman, J. L. (1992). A Practical Guide to Alternative Assessment. Los

Kaufman, J. H., \& Schunn, C. D. (2010). Students' Perception about Peer Assessment for Writing: Their origin and Impact on Revision Work. Journal of Science \& Business, DOI 10.1007/s11251-010-9133-6.

Khotimah, S. (2014). THE USE OF PROBLEM BASED LEARNING TO IMPROVE STUDENTS'SPEAKING ABILITY. In ELT Forum: Journal of English Language Teaching (Vol. 3, No. 1).

Kuliahana, A., \& Marzuki, A. G. (2020). Repetition Technique in an EFL Speaking Class in Islamic Higher Education in Indonesia. Academic Journal Perspective: Education, Language, and Literature, 8(1), 2028.

L. Andrade, \& G. J. Cizek (Eds.), Handbook of Formative Assessment (pp. 69-75). New York, NY: Routledge.

Lam K.W. \& Hassan A. \& Sulaiman T. \& Kamarudin N. (2018). Evaluating the Face and Content Validity of an Instructional Technology Competency Instrument for University Lecturers in Malaysia. International Journal of Academic Research in Business and Social Sciences. 8(5). 367-385. 
Leong, L.M, \& Ahmadi, S.M. (2017). An Analysis of Factors Influencing Learners' English-Speaking Skill. International Journal of Research in English Education, 34-41.

Lin, C. J. (2019). An online peer assessment approach to supporting mindmapping flipped learning activities for college English writing courses. Journal of Computers in Education, 6(3), 385-415.

Mansourzadeh, N. (2014). A comparative study of teaching vocabulary through pictures and audio-visual aids to young Iranian EFL learners. Journal of Elementary Education, 24(1), 47-59.

Marzuki, A. G. (2019). The Implementation of SQ3R Method to Develop Learners' Reading Skill on Islamic Texts in EFL Class in Indonesia. Register Journal, 12(1), 49-61.

Marzuki, A. G. (2019). The Roles of School Principal Leadership in Developing English Teachers' Creativities in Palu. Al-Ta lim Journal, 26(3), 267-279.

Marzuki, A. G. (2019). Utilizing Recorded English Dialogues in Teaching English Word Stress to Islamic Higher Education Learners in Indonesia. Jurnal Pendidikan Islam, 5(1), 53-64.

Marzuki, A. G., Alim, N., \& Wekke, I. S. (2018). Improving the reading comprehension through cognitive reading strategies in language class of coastal area in indonesia. In IOP Conference Series: Earth and Environmental Science, 156(1), 012050). IOP Publishing.

Marzuki, A.G. (2016). Utilizing cooperative learning in islamic college learners' classroom. IJEE (Indonesian Journal of English Education), 3(2), 123-139.

Marzuki, A.G. (2017). Applying mind mapping technique in improving english vocabulary mastery in an efl classroom. Paedagogia: Jurnal Pendidikan, 6(2), 276-293.

Marzuki, A.G. (2017). Utilizing pictures in increasing learners' vocabulary mastery in an efl class in palu city indonesia. Musawa: Journal for Gender Studies, 9(2), 191-233.

Musfirah, Y. (2019). The Use of Peer Assessment in Speaking Skill. English Education Journal, 10(1), 67-79. Practices. New York: Longman. Resources. Journal of University of Hong Kong.

Santiana, S., \& Fatimah, A. S. (2017). Prezi, Cloud-Based Presentation, for Teaching: How is it Interesting?. EduLite: Journal of English Education, Literature and Culture, 2(2), 445-456.

Strijbos, J. W., \& Sluijsmans, D. (2010).Unravelling Peer Assessment: Methodological, Functional, and Conceptual Developments. Learning and Instruction, 20(4), 265-269.

Topping, K. J. (2010).Peers as a Source of Formative Assessment. In: H. 
